in vivo $33: 983-997(2019)$

doi:10.21873/invivo. 11568

Review

\title{
Chemoprevention of Breast Cancer With Vitamins and Micronutrients: A Concise Review
}

\author{
KEFAH MOKBEL and KINAN MOKBEL
}

The London Breast Institute, Princess Grace Hospital, London, U.K.

\begin{abstract}
Numerous dietary components and vitamins have been found to inhibit the molecular events and signalling pathways associated with various stages of breast cancer development. To identify the vitamins and dietary micronutrients that exert protective effects against breast cancer and define their mechanism of action, we performed a literature review of in vitro, animal and epidemiological studies and selected the in vitro and animal studies with robust molecular evidence and the epidemiological studies reporting statistically significant inverse associations for a breast cancer-specific protective effect. There is sufficient evidence from in vitro, animal and epidemiological human studies that certain vitamins, such as vitamin D3, folate, vitamin B6, and beta carotene as well as dietary micronutrients, such as curcumin, piperine, sulforaphane, indole-3-carbinol, quercetin, epigallocatechin gallate (EGCG) and omega-3 polyunsaturated fatty acids (PUFAs), display an antitumoral activity against breast cancer and have the potential to offer a natural strategy for breast cancer chemoprevention and reduce the risk of breast cancer recurrence. Therefore, a supplement that contains these micronutrients, using the safest form and dosage should be investigated in future breast cancer chemoprevention studies and as part of standard breast cancer therapy.
\end{abstract}

Breast cancer remains a very common disease among women, with an annual global incidence of over 2 million cases per year and one of the highest numbers of cancerrelated deaths among women $(1,2)$. The limitations of

This article is freely accessible online.

Correspondence to: Kefah Mokbel, The London Breast Institute, Princess Grace Hospital, 45 Nottingham Place, London W1U, U.K. Tel: +44 02079082040, Fax: +44 02079082275, e-mail: kefahmokbel@ hotmail.com

Key Words: Vitamins, micronutrient, phytochemicals, diet, cruciferous vegetables, breast cancer, chemoprevention, review. current treatment strategies include: i) resistance to drug treatment, ii) significant side-effects and iii) cost. The high incidence and limitations of therapeutic strategies underscore the importance of pursuing prevention strategies that lack significant adverse effects. Numerous dietary components and vitamins have been found to inhibit the molecular events and signalling pathways associated with various stages of breast cancer development and could, therefore, represent potential strategies in breast cancer chemoprevention. A major factor in the effectiveness of these components lies in their natural, raw form. It should be highlighted that cooking can cause considerable losses in essential vitamins and micronutrients (3-7).

\section{Materials and Methods}

We conducted a literature review of epidemiological studies reporting breast cancer-specific risks in relation to serum levels of vitamins and micronutrients. In vitro and animal studies investigating the effects of such micronutrients and vitamins on breast tumours and breast cancer cells were also included in our search. Searches were conducted using the PubMed search engine from inception until May 2019 and the following search terms were used: 'micronutrients, vitamins, diet and breast cancer'. A total of 3793 abstracts that fitted our initial search criteria were further assessed for relevance and consistency and a total of 104 studies were finally selected. Studies demonstrating statistically significant inverse associations (epidemiological studies) or robust molecular evidence (animal and in vitro studies) for a protective effect were selected to identify the vitamins and micronutrients to be covered in our concise review. When conflicting results were found the most updated meta analyses were included in this review. Vitamins and micronutrients associated with no evidence, weak or frequently inconsistent evidence for protective effects against breast cancer were not included in this review. The relative risk (RR) or hazard ratio (HR) and $95 \%$ confidence intervals (CI) were reported for the relevant studies.

\section{Results}

We identified 4 vitamins: i) vitamin D3, ii) folate, iii) vitamin B6, and iv) beta carotene, 2 spices: i) curcumin and ii) piperine and 5 micronutrients: i) sulforaphane, ii) indole-3carbinol, iii) quercetin, iv) epigallocatechin gallate (EGCG) 
and v) omega-3 polyunsaturated fatty acids (PUFAs) associated with lower risks of breast cancer risk and/or recurrence. The epidemiological studies demonstrating the protective effects of these vitamins and micronutrients against breast cancer were assessed and presented in Table I. Results of this literature search for the mechanisms of action by which these vitamins and micronutrients exert their chemopreventive effects on breast cancer are shown in Table II.

Folate (vitamin B9). Vitamin B9 is an essential nutrient that naturally occurs as folate. A pooled analysis of 23 prospective studies involving a total of 41,516 breast cancer cases and 1,171,048 individuals were included for metaanalysis. Folate intake was found to be associated with an $18 \%$ decrease in risk of developing hormone receptor negative breast cancer [relative risk $(\mathrm{RR})=0.82,95 \%$ confidence interval $(\mathrm{CI})=0.68-0.97]$. An increment of folate intake of 100 micrograms per day was associated with a $10 \%$ decrease in risk among women who drink moderate amounts of alcohol ( $\mathrm{RR}=0.90,95 \% \mathrm{CI}=0.85-0.97)(8)$.

Furthermore, BRCA1 mutation carriers who used any folic acid-containing supplement had a significantly decreased risk of breast cancer (55\%) compared to women who never used a folic acid-containing supplement [odds ratio $(\mathrm{OR})=0.45$, 95\% CI $=0.25-0.79, p=0.006]$ (9). Finally, relatively high dietary intake of folate intake was inversely associated with risk of cancer of the womb and the ovaries. Women with folate in the highest quartile had a lower risk of endometrial cancer than those with folate levels in the lowest quartile with $48 \%$ risk reduction $(\mathrm{HR}=0.52 ; 95 \% \mathrm{CI}=0.29-0.93)$. Women in the upper third for folate intake had lower risk of ovarian cancer than those in the lowest third with $61 \%$ risk reduction $(\mathrm{HR}=0.39,95 \% \mathrm{CI}=0.19-0.80)(10)$. Therefore, it makes sense for women to take a daily folate supplement (400 micrograms daily). This is a healthier form of vitamin B9 compared to folic acid.

Vitamin D3. It has been demonstrated that treating breast cancer cells with 1,25-dihydroxy $(\mathrm{OH})$ vitamin D3 induces two beneficial effects: i) an anti-proliferative effect suppressing growth of cells and ii) a pro-apoptotic effect encouraging natural breast cancer cell death $(11,12)$.

A recent meta-analysis of 68 studies published in 2018 showed a protective effect of $1.25(\mathrm{OH}) \mathrm{D} 3$ use and breast cancer, with a $35 \%$ reduction in risk observed in case-control studies $(\mathrm{OR}=0.65,95 \% \mathrm{CI}=0.56-0.76)$ and $15 \%$ risk reduction in cohort studies $(\mathrm{RR}=0.85,95 \% \mathrm{CI}=0.74-0.98)$. Interestingly, the protective vitamin $\mathrm{D}$ - breast cancer association persisted only in premenopausal women, with a $33 \%$ risk reduction $(\mathrm{OR}=0.67,95 \% \mathrm{CI}=0.49-0.92)$, when restricting the analysis to nested case-control studies (13).

A more recent meta-analysis has demonstrated that vitamin D deficiency was directly related to breast cancer risk $\left(\mathrm{RR}_{\text {pooled }}=1.91,95 \% \mathrm{CI}=1.51-2.41, p<0.001\right)$ while total blood vitamin D levels $\left(\mathrm{RR}_{\text {pooled }}=0.99,95 \% \mathrm{CI}=0.97-1.00\right.$, $p=0.022$, per $100 \mathrm{IU} / \mathrm{d})$ and supplemental vitamin $\mathrm{D}$ intakes $\left(\mathrm{RR}_{\text {pooled }}=0.97,95 \% \mathrm{CI}=0.95-1.00, \quad p=0.026\right)$ had a protective effect (14).

Finally, a meta-analysis of five studies including 4,413 breast cancer patients showed that higher $1.25(\mathrm{OH}) \mathrm{D}_{3}$ levels $(>75 \mathrm{nmol} / \mathrm{l})$ were associated with a $42 \%$ reduction in the odds of dying from breast cancer $\left(\mathrm{HR}_{\text {pooled }}=0.58\right.$, $95 \% \mathrm{CI}=0.38-0.84)(15)$.

Vitamin B6. Vitamin B6 is involved in many biochemical reactions and may play a role in carcinogenesis. A combined analysis of data derived from 5 studies carried out in the United States, including 2,509 breast cancer cases, has showed that high serum pyridoxal 5'-phosphate levels (PLP is the active form of vitamin B6) were associated with a $20 \%$ reduction in breast cancer risk compared to low levels among postmenopausal women [combined RR for the highest versus lowest serum PLP levels was $0.80,95 \% \mathrm{CI}=0.66-0.98$, $p=0.03](16)$.

A more comprehensive analysis in 2017 of 121 observational studies (participants $=1,924,506$, cancer cases $=96,436$ ) and 9 randomized controlled trials (RCTs) (participants $=34,911$, cases $=2539$ ) considering 19 tumour sites revealed that high intake of dietary (food only) vitamin B6 was significantly associated with $22 \%$ lower risk of all cancers $(\mathrm{RR}=0.78,95 \% \mathrm{CI}=0.73-0.84)(17)$.

Beta Carotene. Beta carotene is a precursor for vitamin A and is found predominantly in carrots, mango, maize, lentils, dark green leaves, amaranth, and spinach. A pooled analysis of eight cohort studies comprising more than $80 \%$ of the world's published prospective data on plasma or serum carotenoids and breast cancer, including 3,055 case subjects and 3,956 matched control subjects, revealed that high serum levels of beta carotene are associated with a $17 \%$ reduction in breast cancer risk (top versus bottom quintile $\mathrm{RR}=0.83$, $95 \% \mathrm{CI}=0.70-0.98, p$-trend=0.02) (18). Furthermore, a metaanalysis of 10 studies ( 8 cohort, 1 clinical trial, and 1 pooled study) with 19,450 breast cancer cases, has shown that the dietary intake of $\beta$-carotene is significantly associated with improved breast cancer survival with a $30 \%$ reduction in the odds of dying from breast cancer [summary $\mathrm{HR}=0.70$ $\left(95 \% \mathrm{CI}=0.50-0.99, I^{2}=37.5 \%\right)$ for the highest versus lowest intake of $\beta$-carotene] (19). In a large prospective analysis with 20 years of follow-up, women with high plasma carotenoids were at reduced breast cancer risk, particularly for more aggressive and ultimately fatal disease. Higher concentrations of $\beta$-carotene were associated with $28 \%$ significantly lower risk of breast cancer $(\beta$-carotene top versus bottom quintile $\mathrm{RR}=0.72,95 \% \mathrm{CI}=0.59-0.88, p$ trend<0.001) (20). 
Table I. Summary of studies selected in our review reporting on risk estimates of the associations between intake of selected vitamins and micronutrients (highest vs. lowest) and breast cancer risk.

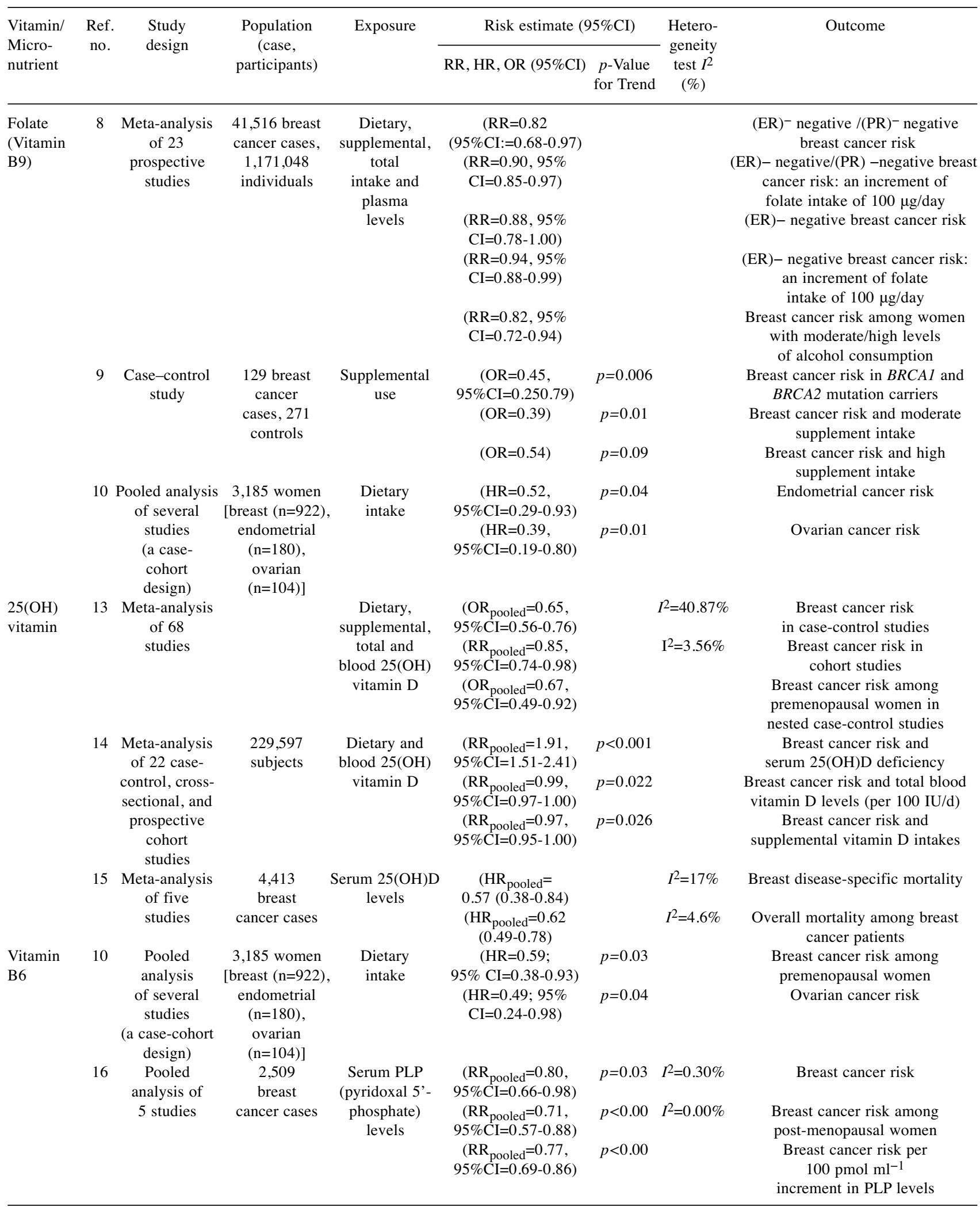


Table I. Continued

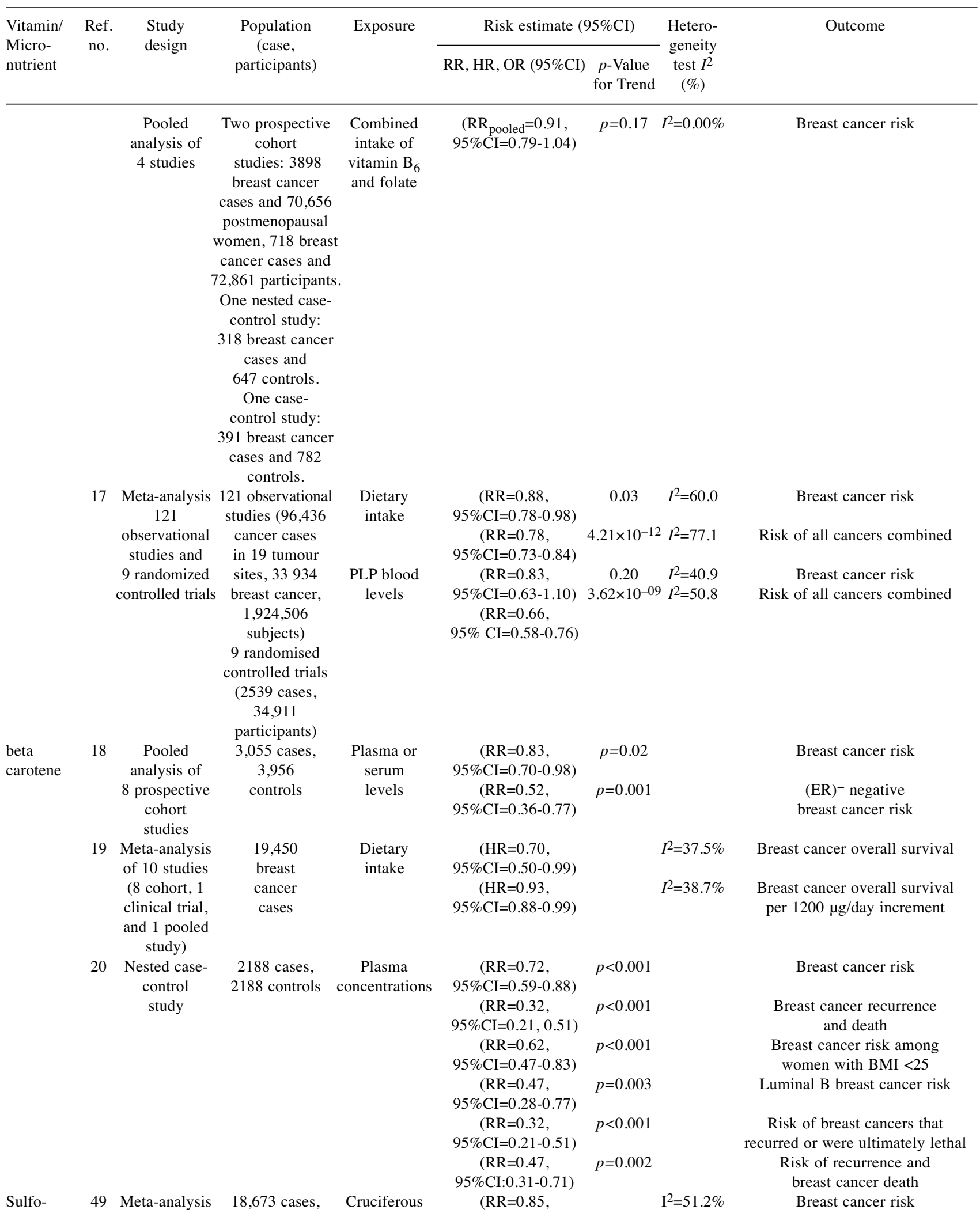


Table I. Continued

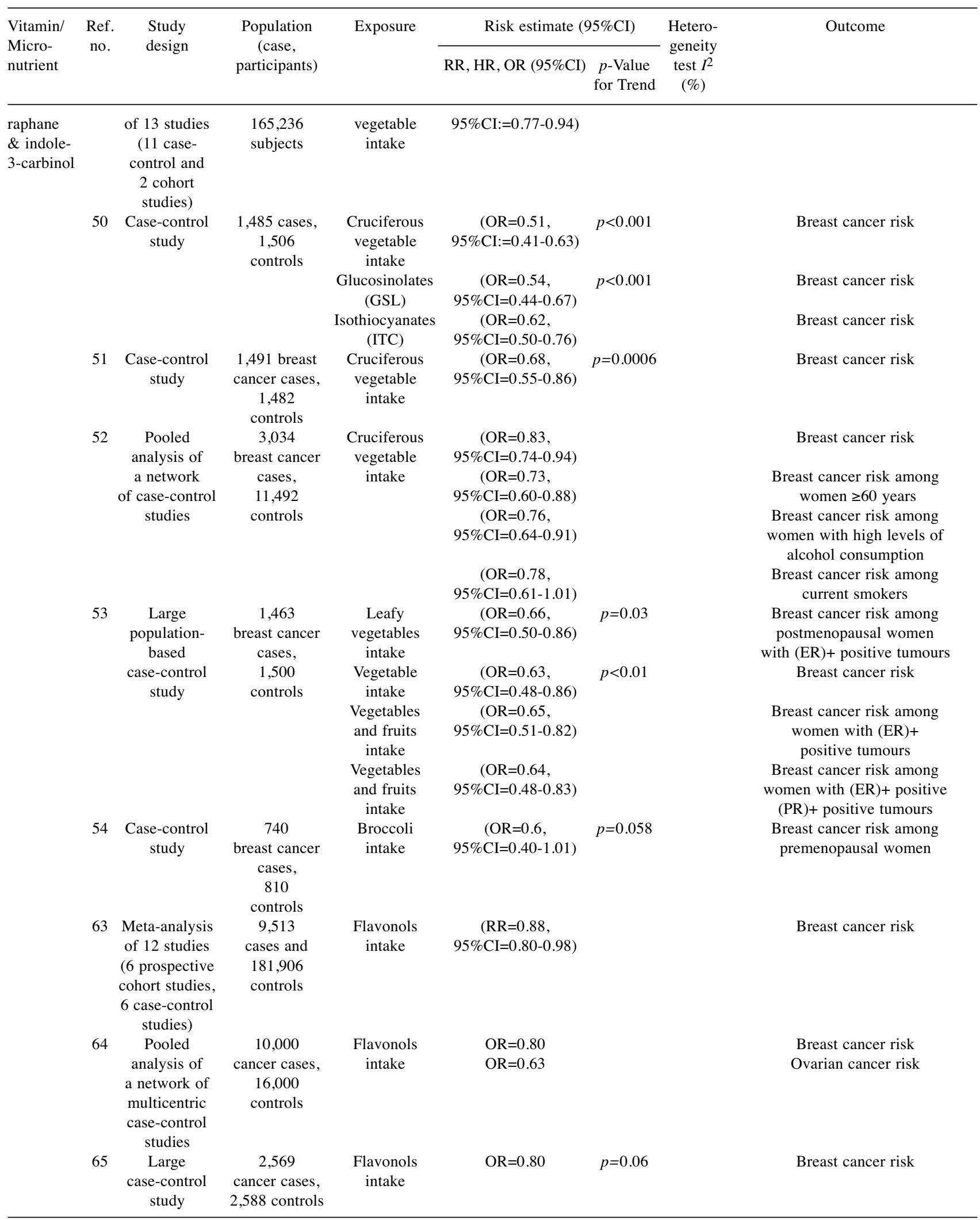


Table I. Continued

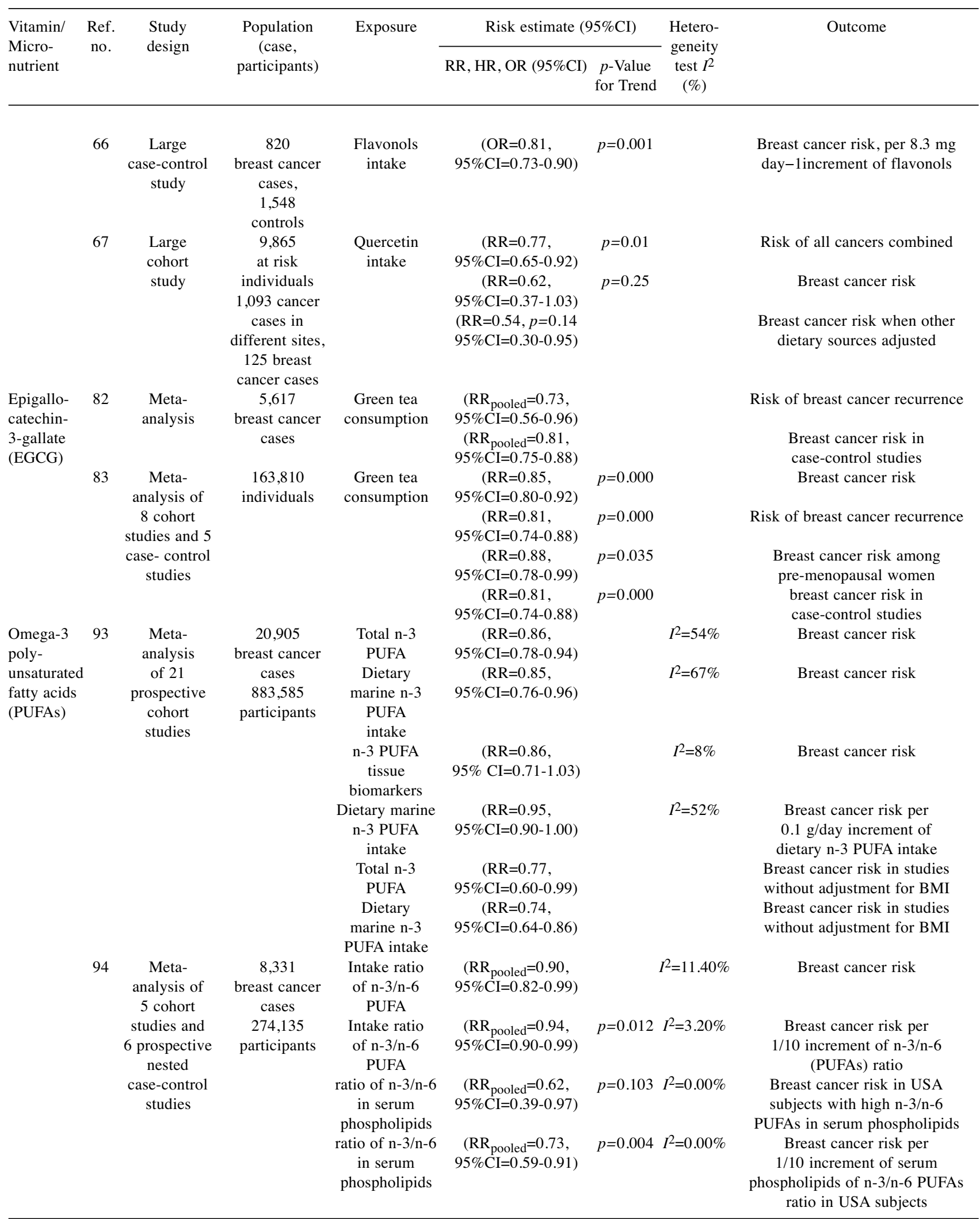

CI: Confidence Interval; RR: relative risk; HR: hazard ratio: OR: odds ratio; ER: oestrogen receptor; PR: progesterone receptor. 
Table II. Summary of the mechanisms of action of the micronutrients and spices against breast cancer

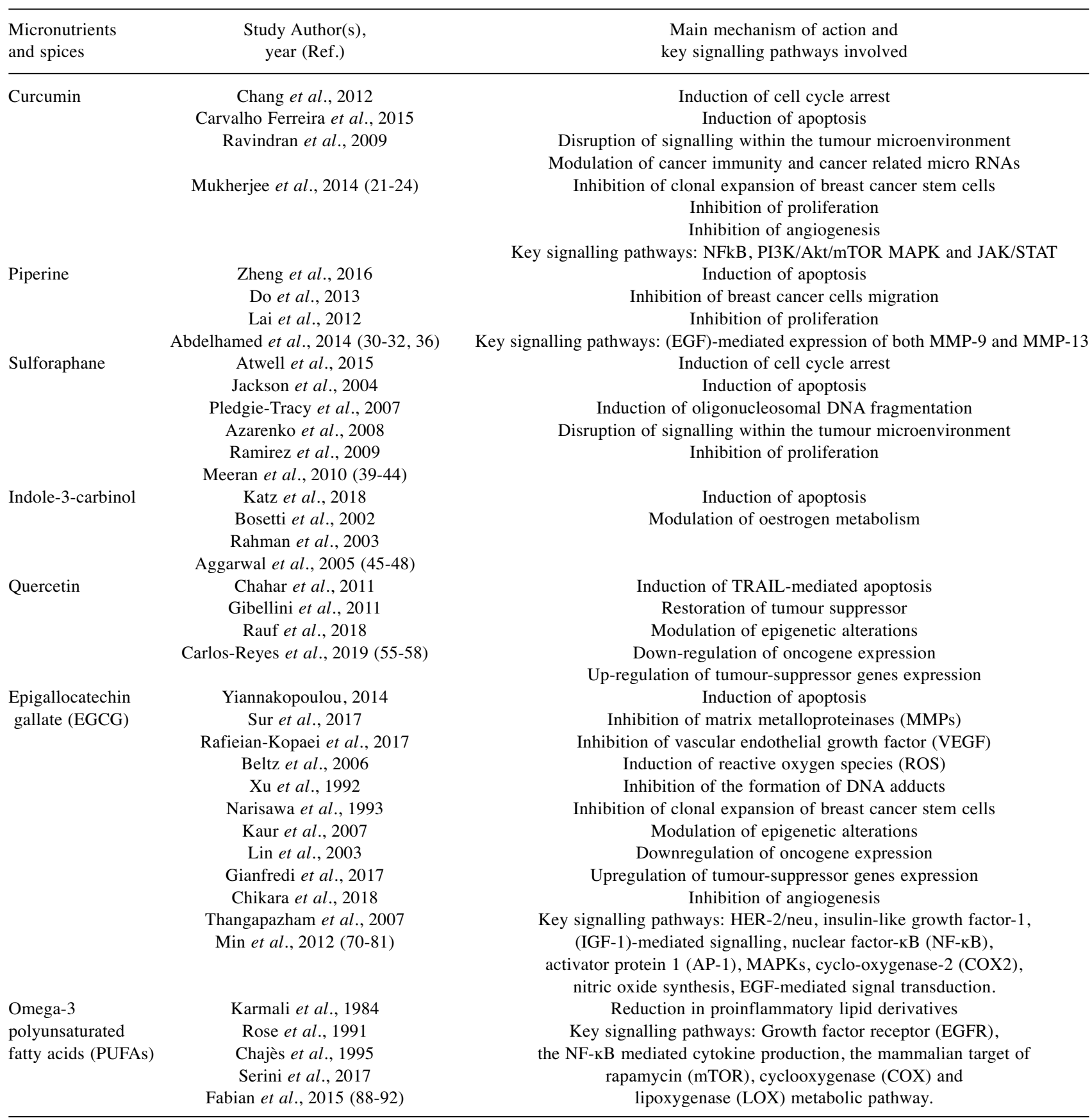

Curcumin and piperine. Turmeric is a yellow spice with a specific flavour used in Asian cuisine. Curcumin, a polyphenolic compound, is a secondary metabolite isolated from turmeric. The anti-breast-cancer effects of Curcumin came mainly from investigators of animal and laboratory studies.
Curcumin influences breast development and progression through its effect on cell cycle and proliferation, natural cell death, cancer spread and development of new blood supply to support tumour progression $(21,22)$. The key signalling pathways involved include the NFkB, PI3K/Akt/mTOR, MAPK and JAK/STAT (23). Curcumin also mediates the 
modulation of the tumour microenvironment, cancer immunity, breast cancer stem cells and cancer-related micro RNAs (24). The chemopreventive effect of curcumin towards mammary tumorigenesis has been observed in both the initiation and postinitiation phases and has been found to significantly inhibit the initiation of mammary adenocarcinoma $(25,26)$.

Despite the lack of evidence from human clinical studies, using curcumin as a therapeutic and preventive agent in breast cancer is supported by the extensive evidence derived from laboratory and animal studies, demonstrating a diverse biological activity against breast cancer cells and tumours, much of which remains inexplicable (27). Concomitant administration of piperine significantly enhances the extent of absorption, serum concentration and bioavailability of curcumin in humans up to 20-fold $(28,29)$.

Piperine has also been proved to exert anti breast cancer properties, mainly by inhibiting proliferation and promoting apoptosis (30). Experimental data have demonstrated that piperine can inhibit hormone-dependent breast cancer cells and strongly suppress epidermal growth factor (EGF)mediated expression of both MMP-9 and MMP-13 in breast cancer cells, which is activated in up to one-third of breast cancer patients, leading to an inhibition of the migration of breast cancer cells $(31,32)$. In studying the anticancer effect of bioactive phytochemicals combined with conventional cancer therapies, piperine was found to potentiate the cytotoxicity of anti-cancer drugs and even reverse multi-drug resistance that impairs the efficacy of chemotherapy (33).

Furthermore, piperine has been found to enhance the sensitisation of HER2-overexpressing breast cancer cells to paclitaxel $\left(\right.$ Taxol ${ }^{\circledR}$ ), a chemotherapy medication used to treat breast cancer $(31,34)$. A synergistic effect has also been observed with Tamoxifen against breast cancer cells (35). In triple-negative breast cancer, which is the most aggressive type of breast cancer and is poorly responsive to endocrine therapeutics, piperine has been found to trigger apoptosis via the mitochondrial pathway and augment the effectiveness of TRAIL-based therapeutics (36). In studying the combination of piperine with radiotherapy, the first was found to enhance the $\gamma$ radiation cytotoxicity for triple-negative breast cancer and the combination of piperine and curcumin can sensitise breast cancer cells to radiation in a dose dependent manner $(37,38)$.

Sulforaphane and indole-3-carbinol. Numerous studies investigating the association of cruciferous vegetables intake with risk of breast cancer have reported that consumption of cruciferous vegetables has a protective effect in breast cancer, largely attributed to sulforaphane and Indole-3-carbinol.

Sulforaphane is an isothiocyanate phytochemical from cruciferous vegetables with multiple molecular targets, antiinflammatory, antioxidant and anti-cancer properties. Researchers have reported several chemo-prevention benefits of Sulforaphane consumption.
Several studies have demonstrated that sulforaphane influences human cancer development and progression through the modulation and/or regulation of cell cycle and key cellular mechanisms, such as reduction in tumour growth, induction of cell cycle arrest, activation of programmed cell death and disruption of signalling within the tumour microenvironment (39). In human breast cancer cells, sulforaphane has been found to inhibit cell growth, induce $\mathrm{a}_{2} / \mathrm{M}$ cell cycle block, increase expression of cyclin $\mathrm{B} 1$, induce oligonucleosomal DNA fragmentation, activate apoptosis and decrease the expression of key proteins involved in breast cancer proliferation (40-44).

Indole-3-carbinol is another phytochemical, produced by the breakdown of the glucosinolates that are found at relatively high levels in cruciferous vegetables. Indole-3carbinol has been shown to be a potent chemo-preventative agent for hormone-dependent breast cancer through its ability to selectively induce apoptosis and alter oestrogen metabolism (45-48).

A meta-analysis of thirteen epidemiologic studies (11 case-control and 2 cohort studies) has indicated that high consumption of cruciferous vegetables was significantly associated with $15 \%$ reduction in breast cancer risk ( $\mathrm{RR}=0.85,95 \% \mathrm{CI}=0.77-0.94)$ (49). In a more recent study involving 1,485 cases and 1,506 controls, intake of cruciferous vegetables significantly reduced the breast cancer risk by almost $50 \%$ in the Chinese population. The chemoprevention benefit of cruciferous diet is largely attributed to sulforaphane and Indole-3-carbinol (50).

In another case-control study in 1,491 patients with breast cancer and 1,482 controls, cruciferous vegetable intake was associated with a $32 \%$ reduction in breast cancer risk (highest versus lowest quartile $\mathrm{OR}=0.68,95 \% \mathrm{CI}=0.55$ $0.86, p$-trend $=0.0006$ ). Cruciferous vegetables contain high concentrations of glucosinolates (mainly sulforaphane) that are hydrolysed by the intestinal microflora to isothiocyanates; (51). A meta-analysis of studies conducted over 18 years in Europe included a total of 3,034 of breast cancer patients and 11,492 controls showed that the multivariate odds ratio for consumption of cruciferous vegetables was significantly reduced for breast cancer $(\mathrm{OR}=0.83)(52)$.

Furthermore, in a case-control study involving 1,463 cases and 1,500 controls, an inverse association between consuming cruciferous vegetables and breast cancer was reported, mainly for postmenopausal women, with oestrogen receptor $(\mathrm{ER})+$ tumours $[\mathrm{OR}=0.66,95 \% \mathrm{CI}=0.50-0.86, p$ trend=0.03] (53). Similarly, in another case-control study involving 740 Caucasian women with breast cancer and 810 controls, inverse associations were noted between consumption of cruciferous vegetables and breast cancer risk, predominantly among premenopausal women [4th quartile $\mathrm{OR}=0.6,95 \% \mathrm{CI}=0.40-1.01, p=0.058](54)$. 
Quercetin. Quercetin is a bioactive flavonoid pigment found in several fruits, vegetables and leaves. In addition to its free-radical scavenging antioxidant activity, quercetin has been reported to exert potent anti-tumoral properties.

Studies suggest that quercetin's cancer-protecting effects result from triggering TRAIL-mediated cancer cell death and targeting key signalling transducers, leading to the restoration of tumour suppressor genes and inhibition of oncogene expression (55-57). Besides, quercetin was found to reverse epigenetic alterations associated with oncogenes' activation and inactivation of tumour suppressor genes (58).

Quercetin can successfully reverse multidrug resistance and restore chemosensitivity to cyclophosphamide in human chemo-resistant triple-negative breast cancer cells (59). Also, quercetin has been found to augment doxorubicin chemotherapeutic effects against human breast cancer cells and reduce its cytotoxic side effects (doxorubicin is a firstline chemotherapeutic for breast cancer, however, its toxic side effects in normal tissues limit its clinical use) $(60,61)$. Quercetin may also inhibit angiogenesis in acquired tamoxifen-resistant breast cancer cells, which is a serious therapeutic problem among breast cancer patients (62).

In a meta-analysis of twelve studies (including 9,513 cases and 181,906 controls, 6 of which were prospective cohort studies, and 6 were case-control studies), the risk of breast cancer was significantly decreased by $12 \%$ in women with high intake of flavonols, including quercetin compared to those with low consumption $(\mathrm{RR}=0.88,95 \% \mathrm{CI}=0.80-0.98)$ (63). In a network of multicentric Italian case-control studies (10,000 cancer cases and 16,000 controls), a reduced breast cancer risk by $20 \%$ and ovarian cancer risk by $37 \%$ were reported in the cohort with a high intake of flavonols, such as quercetin (ORs for the highest vs. the lowest quintile were 0.80 and 0.63 , respectively) $(64,65)$. Similarly, in a large Greek case-control study involving 820 women with breast cancer and 1,548 controls, an inverse association with breast cancer risk was found for consumption of flavonols in fruits, including quercetin (66). Finally, the Finnish Mobile Clinic Health Examination Survey involving a total of 10,054 individuals with 1,093 cancer cases has reported that the total cancer incidence was significantly lower with a higher consumption of quercetin (RR between the highest and lowest quartiles of quercetin intake $=0.77,95 \% \mathrm{CI}=0.65-0.92$, $p=0.01$ ). Breast cancer risk was also found to be lower at higher consumption of quercetin $(\mathrm{RR}=0.62,95 \% \mathrm{CI}=0.37$ $1.03 ; p=0.25)$. This association was even stronger when adjustment for other dietary sources were made $(\mathrm{RR}=0.54$, $95 \% \mathrm{CI}=0.30-0.95, p=0.14)(67)$.

Epigallocatechin-3-gallate (EGCG). Green tea has been extensively studied for its potential protective effect from various types of human cancers. Compared to other teas, green tea contains the highest amount of bioactive compounds that belong to the polyphenol group (68). Scientific literature has presented evidence that green tea exerts protective effects against tumorigenesis owing to its principal polyphenol, namely epigallocatechin-3-gallate (EGCG) (69).

Evidence from several laboratory studies has demonstrated the strong chemopreventive and potentially cancer chemotherapeutic effects of the major green tea constituent, epigallocatechin-3-gallate (EGCG), against breast cancer (70). Most experimental data have shown that green polyphenols can modulate multiple signalling pathways and regulate the growth, survival and metastasis of cancer cell at multiple levels $(71,72)$.

In addition to the inhibition of clonal expansion of cancer stem cells and the modulation of tumour progression by maintaining a quiescent state in cancer cells, green tea (EGCG) can modulate multiple cell signalling pathways implicated in angiogenesis, metastasis and invasion, such as the inhibition of matrix metalloproteinases (MMPs) and the inhibition of vascular endothelial growth factor (VEGF). EGCG has also been reported to inhibit activator protein 1 and MAPKs, cyclo-oxygenase- 2 overexpression, proteasome activity, nitric oxide synthesis, HER-2/neu signalling, insulin-like growth factor-1 (IGF-1)-mediated signalling and nuclear factor-kB (NF-kB) signalling pathways. EGCG has been found to suppress the binding of epidermal growth factor (EGF) to its receptor, leading to the inhibition of EGFmediated signal transduction pathways (73).

Moreover, previous studies have shown that green tea's major constituent (EGCG) can decrease tumorigenicity by inhibiting the formation of DNA adducts, which are alterations in DNA that result from exposure to carcinogens and affect directly the regulation of transcription of oncogenes and/or tumour suppressors (74-77). Green tea polyphenols can also down-regulate oncogenes and upregulate tumour-suppressor genes via modulating multiple epigenetic events (78). Data from in vitro and in vivo studies have shown that green tea polyphenols can induce programmed cell death in breast cancer cells either by a preferential cancer-specific induction of reactive oxygen species (ROS) or by epigenetic modulation of expression of apoptosis-related genes, such as human telomerase reverse transcriptase (hTERT) (79-81).

A meta-analysis of breast cancer incidence and recurrence involving 5,617 cases of breast cancer, has shown that green tea consumption is inversely associated with the risk of breast cancer recurrence $\left(\mathrm{RR}_{\text {pooled }}=0.73,95 \% \mathrm{CI}=0.56-0.96\right)$. When only the case-control studies of breast cancer incidence were examined, the inverse association was maintained $\left(\mathrm{RR}_{\text {pooled }}=0.81,95 \% \mathrm{CI}=0.75-0.88\right)(82)$. In line with the previous meta-analysis, a more recent systematic review and meta-analysis of several observational studies encompassing 163,810 people, has reported a statistically significant inverse relationship between green tea 
consumption and breast cancer risk with a reduction of risk by $15 \%[(\mathrm{OR})=0.85(95 \% \mathrm{CI}=0.80-0.92), p=0.000]$. When only the case-control studies were analysed, the protective effect observed was even higher, being $19 \%$ reduction in breast cancer risk $[(\mathrm{OR})=0.81(95 \% \mathrm{CI}=0.74-0.88), p=0.000]$. The significance of case-control studies in defining the causal relationship between exposure and event cannot be overemphasised. Finally, in a sensitivity analysis of the studies with high quality scores included in this metaanalysis, the reduction of breast cancer risk reported was even higher, at $27 \%$ (83).

Omega-3 fatty acids (PUFAs). Epidemiological studies indicated that the relatively higher incidence of breast cancer in developed countries in Western Europe and North America compared to the Inuit and the Japanese can explained by the variation in dietary patterns, in particular variations concerning intake of fatty fish and fat from marine mammals, which may be key modifiers of breast cancer risk (84-86). This preventive effect towards breast cancer has been attributed to the very high dietary intake of marine polyunsaturated fatty acids (PUFAs), mainly omega-3 PUFAs (n-3 PUFA) and omega-6 PUFAs (n-6 PUFA), found in fatty cold-water fish and fat from marine mammals (87).

The protective effect of polyunsaturated fatty acids against breast carcinogenesis was supported by multiple animal experiments and in vitro studies (88-91). Current evidence from experimental studies has shown that ratio of $n-3 / n-6$ PUFAs can reduce the amount of proinflammatory lipid derivatives, growth factor receptor signalling, the NF-kB mediated cytokine production, and can modulate the signal transduction mediated by the mammalian target of rapamycin (mTOR) and the growth of breast cancer cells, by competing for cyclooxygenase and lipoxygenase metabolic pathway (92). However, the precise molecular mechanism by which these marine PUFAs can affect carcinogenesis and angiogenesis of breast cancer remains to be unequivocally defined.

In order to examine the association between the risk of breast cancer and dietary n-3 PUFA intake, a meta-analysis of data from 21 independent prospective cohort studies involving 20,905 breast cancer events and 883,585 participants was performed. Higher consumption of n-3 PUFA has been reported to be associated with a $14 \%$ reduction in breast cancer risk [RR for highest vs. lowest category $\left.0.86\left(95 \% \mathrm{CI}=0.78-0.94, I^{2}=54 \%\right)\right]$. This relative risk was independent of whether n-3 PUFA is measured as dietary intake [RR for highest versus lowest category 0.85 , $\left.\left(95 \% \mathrm{CI}=0.76-0.96, I^{2}=67 \%\right)\right]$ or as tissue biomarkers $[\mathrm{RR}$ for highest versus lowest category 0.86 , (95\% CI=0.71-1.03, $\left.\left.I^{2}=8 \%\right)\right]$. The dose-response analysis showed that risk of breast cancer can decrease by a $5 \%$ per $0.1 \mathrm{~g} /$ day increment of dietary n-3 PUFA intake (relative risk $=0.95,95 \% \mathrm{CI}=0.90$ $\left.1.00, I^{2}=52 \%\right)(93)$.
To quantitatively ascertain the relationship between the risk of breast cancer and high intake ratios of n-3/n-6 PUFAs, a meta-analysis of five cohort studies and six prospective nested case-control studies, involving 8,331 cases of breast cancer from 274,135 adult females from several countries was performed. Among study populations, individuals with higher dietary intake ratios of the omega-3 to omega-6 (PUFAs) were reported to have a significantly reduced risk of breast cancer $\left(\mathrm{RR}_{\text {pooled }}=0.90,95 \% \mathrm{CI}=0.82-0.99\right)$. When the dose-response association was analysed, an increment per $1 / 10$ of $n-3 / n-6$ (PUFAs) ratio in diet was associated with a further $6 \%$ reduction of breast cancer risk $\left(\mathrm{RR}_{\text {pooled }}=0.94,95 \% \mathrm{CI}=0.90\right.$ $0.99, p$ for linear trend=0.012). More importantly, the subgroup analysis has shown that individuals in 3 studies from USA with higher intake ratios of $n-3 / n-6$ in serum phospholipids had a $38 \%$ reduction of breast cancer risk $\left(\mathrm{RR}_{\text {pooled }}=0.62, \quad 95 \% \mathrm{CI}=0.39-0.97, \quad I^{2}=0.00 \% ; \quad p\right.$ for metaregression $=0.103, p$ for a permutation test $=0.100$ ). When the dose-response association was evaluated as above, an increment per $1 / 10$ of serum phospholipids of omega- 3 to omega-6 (PUFAs) ratio was associated with a $27 \%$ reduction of breast cancer risk $\left(\mathrm{RR}_{\text {pooled }}=0.73,95 \% \mathrm{CI}=0.59-0.91, p\right.$ for linear trend $=0.004, p$ for meta-regression $=0.082 ; p$ for a permutation test=0.116). As EPA and DHA cannot be synthesised de novo in mammals and inter-conversion between n-3 and n-6 polyunsaturated fatty acids does not exist in humans, serum phospholipids of omega-3 to omega-6 (PUFAs) ratios reflect their dietary intake ratios (94).

Alpha-linolenic acid, which is one of the most abundant omega-3 polyunsaturated fatty acid in typical Western diets, is metabolised to two long-chain n-3 PUFAs, namely eicosapentaenoic acid (EPA) and docosahexaenoic acid (DHA) (95). Typical consumption of alpha-linolenic acid among Western adults is in the range of $0.5-2 \mathrm{~g} / \mathrm{d}$ which is approximately 15- and 25-fold higher than of DHA and EPA, respectively (96-100). As human conversion of alpha-linolenic acid to its longer-chain derivatives EPA \& DHA is inefficient, very high intakes of alpha-linolenic acid are required to allow sufficient synthesis of its longer-chain derivatives EPA \& DHA $(99,101)$. While the total percentage of conversion of alpha-linolenic acid to EPA \& DHA varies widely, ranging from $5-18.5 \%$, it has been reported that $2.8 \%$ of dietary alphalinolenic acid consumed is converted to EPA and that less than $1-4 \%$ of dietary alpha-linolenic acid is converted to DHA (102, 103). Furthermore, although the relationship between increased alpha-linolenic acid intake and increased EPA concentration in plasma and tissue lipids is linear, several studies revealed a tendency for DHA to decline when alphalinolenic acid consumption is markedly increased (99). Moreover, the recent increased intake of linoleic acid, which is the main polyunsaturated fatty acid in most Western diets and is typically consumed in 5- to 20-fold greater amounts than alpha-linolenic acid, has been found to decrease tissue 
concentrations of EPA and DHA $(100,104)$. Additionally, the choice of cooking oil and cooking method (particularly deep frying) can also qualitatively and quantitatively influence the total fatty acid content in cooked fish $(6,7)$.

The limited conversion from dietary alpha-linolenic acid and the increased consumption of linoleic acid as well as the variation in choice of cooking method imply that protective breast tissue levels of EPA \& DHA can be achieved only by direct consumption of these polyunsaturated fatty acids (105, 106). It has been evidenced that omega-3 supplementation reaches and imparts significant improvements in the ratio of n-3/n-6 PUFAs at the target breast tissue (107). This justifies a reconsideration of the dietary reference intake for EPA \& DHA and provides solid and robust evidence that supports breast cancer prevention by increasing consumption of dietary intake ratios of n-3/n-6 PUFAs.

\section{Conclusion}

The protective action of particular vitamins, such as vitamin D3, folate, vitamin B6, and beta carotene, and certain dietary micronutrients, namely curcumin, piperine, sulforaphane, indole-3-carbinol, quercetin, epigallocatechin gallate (EGCG) and n-3/n-6 polyunsaturated fatty acids (PUFAs), against breast cancer via inhibition of proliferation, invasion, angiogenesis and metastasis is well documented. Since breast cancer is now widely recognised as an even more heterogeneous disease than ever envisioned with aberrations in diverse sets of genes, such agents with multi-targeted 'pleiotropic' effects have the potential to be chemopreventive due to their capability to inhibit multiple molecular events and signalling pathways associated with various stages of breast carcinogenesis. The limitations of epidemiological association studies related to confounding lifestyle and genetic factors pertaining to causal inferences are largely overcome by supportive evidence derived from in vivo and mechanistic in vitro studies. Therefore, a supplement that contains these micronutrients using the safest formulation and dosage should be investigated in future breast cancer chemoprevention studies and as part of standard breast cancer treatment. In the absence of such trials, which could prove challenging to conduct and analyse, it would be prudent for women, especially those at an increased risk, to consider these compounds for breast cancer chemoprevention using dietary sources or specific supplements.

\section{References}

1 World Health Organization (WHO): Breast cancer. 2018 Available from: https://www.who.int/cancer/prevention/ diagnosis-screening/breast-cancer/en/ [Accessed 2019 May 29]

2 World Cancer Research Fund (WCRF): Breast cancer statistics. 2018. Available from: https://www.wcrf.org/dietandcancer/ cancer-trends/breast-cancer-statistics [Accessed 2019 May 29]
3. United States Department of Agriculture (USDA), National Agricultural Library: Table of Nutrient Retention Factors, Release 6 (2007). Available from: https://data.nal.usda.gov/ dataset/usda-table-nutrient-retention-factors-release-6-2007 [Accessed 2019 May 29]

4 Bongoni R, Verkerk R, Steenbekkers B, Dekker M and Stieger $\mathrm{M}$ : Evaluation of different cooking conditions on broccoli (Brassica oleracea var. italica) to improve the nutritional value and consumer acceptance. Plant Foods Hum Nutr 69(3): 228-234, 2014. PMID: 24853375. DOI: 10.1007/s11130-0140420-2

5 Prodanov M, Sierra I and Vidal-Valverde C: Influence of soaking and cooking on the thiamin, riboflavin and niacin contents of legumes. Food Chem 84(2): 271-277, 2014. DOI: 10.1016/ S0308-8146(03)00211-5

6 Neff MR, Bhavsar SP, Braekevelt E and Arts MT: Effects of different cooking methods on fatty acid profiles in four freshwater fishes from the Laurentian Great Lakes region. Food Chem 164: 544-550, 2014. PMID: 24996368. DOI: 10.1016/ j.foodchem.2014.04.104

7 Sala-Vila A and Calder PC: Update on the Relationship of Fish Intake with Prostate, Breast, and Colorectal Cancers. Crit Re Food Sci Nutr 51(9): 855-871, 2011. PMID: 21888535. DOI: $10.1080 / 10408398.2010 .483527$

8 Zeng J, Wang K, Ye F, Lei L, Zhou Y, Chen J, Zhao G and Chang H: Folate intake and the risk of breast cancer: an up-todate meta-analysis of prospective studies. Eur J Clin Nutr 1, 2019. PMID: 30647438. DOI: 10.1038/s41430-019-0394-0

9 Kim SJ, Zhang CX, Demsky R, Armel S, Kim YI, Narod SA and Kotsopoulos J: Folic acid supplement use and breast cancer risk in BRCA1 and BRCA2 mutation carriers: a case-control study. Breast Cancer Res Treat 174(3): 741-748, 2019. PMID: 30603998. DOI: 10.1007/s10549-018-05118-3

10 Arthur RS, Kirsh VA and Rohan TE: Dietary B-vitamin intake and risk of breast, endometrial, ovarian and colorectal cancer among Canadians. Nutr Cancer, 2019. PMID: 30955365. DOI: 10.1080/01635581.2019.1597904

11 Simboli-Campbell M, Narvaez CJ, Tenniswood M and Welsh $\mathrm{J}$ : 1,25-Dihydroxyvitamin $\mathrm{D}_{3}$ induces morphological and biochemical markers of apoptosis in MCF-7 breast cancer cells. J Steroid Biochem Mol Biol 58(4): 367-376, 1996. PMID: 8903420. DOI: 10.1016/0960-0760(96)00055-6

12 Welsh J: Induction of apoptosis in breast cancer cells in response to vitamin D and antiestrogens. Biochem Cell Biol 72(11-12): 537-545, 1994. PMID: 7654327. DOI: 10.1139/o94072

13 Estébanez N, Gómez-Acebo I, Palazuelos C, Llorca J and Dierssen-Sotos T: Vitamin D exposure and Risk of Breast Cancer: a meta-analysis. Sci Rep 8(1): 9039, 2018. PMID: 29899554. DOI: 10.1038/s41598-018-27297-1

14 Hossain S, Beydoun MA, Beydoun HA, Chen X, Zonderman $\mathrm{AB}$ and Wood RJ: Vitamin D and breast cancer: A systematic review and meta-analysis of observational studies. Clin Nutr ESPEN 30: 170-184, 2019. PMID: 30904218. DOI: 10.1016/ j.clnesp.2018.12.085

15 Maalmi H, Ordóñez-Mena JM, Schöttker B and Brenner H: Serum 25-hydroxyvitamin D levels and survival in colorectal and breast cancer patients: Systematic review and meta-analysis of prospective cohort studies. Eur J Cancer 50(8): 1510-1521, 2014. PMID: 24582912. DOI: 10.1016/j.ejca.2014.02.006 
$16 \mathrm{Wu}$ W, Kang S and Zhang D: Association of vitamin B6, vitamin B12 and methionine with risk of breast cancer: a doseresponse meta-analysis. Br J Cancer 109(7): 1926-1944, 2013. PMID: 23907430. DOI: 10.1038/bjc.2013.438

17 Mocellin S, Briarava M and Pilati P: Vitamin B6 and Cancer Risk: A field synopsis and meta-analysis. JNCI J Natl Cancer Inst 109(3): 1-9, 2017. PMID: 28376200. DOI: 10.1093/jnci/ djw230

18 Eliassen AH, Hendrickson SJ, Brinton LA, Buring JE, Campos H, Dai Q, Dorgan JF, Franke AA, Gao YT, Goodman MT and Hallmans G: Circulating carotenoids and risk of breast cancer: pooled analysis of eight prospective studies. JNCI J Natl Cancer Inst 104(24): 1905-1916, 2012. PMID: 23221879. DOI: $10.1093 /$ jnci/djs461

$19 \mathrm{He} \mathrm{J,} \mathrm{Gu} \mathrm{Y} \mathrm{and} \mathrm{Zhang} \mathrm{S:} \mathrm{Vitamin} \mathrm{A} \mathrm{and} \mathrm{Breast} \mathrm{Cancer}$ Survival: A Systematic Review and Meta-analysis. Clin Breast Cancer 18(6): e1389-1400, 2018. PMID: 30190194. DOI: 10.1016/j.clbc.2018.07.025

20 Eliassen AH, Liao X, Rosner B, Tamimi RM, Tworoger SS and Hankinson SE: Plasma carotenoids and risk of breast cancer over 20 y of follow-up. Am J Clin Nutr 101(6): 1197-1205, 2015. PMID: 25877493. DOI: 10.3945/ajen.114.105080

21 Chang C-C, Fu C-F, Yang W-T, Chen T-Y and Hsu Y-C: The cellular uptake and cytotoxic effect of curcuminoids on breast cancer cells. Taiwan J Obstet Gynecol 51(3): 368-374, 2012. PMID: 23040919. DOI: 10.1016/j.tjog.2012.07.009

22 Carvalho Ferreira L, S Arbab A, Victorasso Jardim-Perassi B, Ferraz Borin T, RS Varma N, Iskander AS, Shankar A, M Ali $\mathrm{M}$ and Aparecida Pires de Campos Zuccari D: Effect of curcumin on pro-angiogenic factors in the xenograft model of breast cancer. Anti-Cancer Agents Med. Chem 15(10): 12851296, 2015. PMID: 25991545. DOI: $10.2174 / 1871520615666$ 150520093644

23 Ravindran J, Prasad S and Aggarwal BB: Curcumin and cancer cells: how many ways can curry kill tumor cells selectively? AAPS J 11(3): 495-510, 2009. PMID: 19590964. DOI: 10.1208/s12248-009-9128-x

24 Mukherjee S, Mazumdar M, Chakraborty S, Manna A, Saha S, Khan P, Bhattacharjee P, Guha D, Adhikary A, Mukhjerjee S and Das T: Curcumin inhibits breast cancer stem cell migration by amplifying the E-cadherin/ $\beta$-catenin negative feedback loop. Stem Cell Res Ther (5): 116, 2014. PMID: 25315241. DOI: $10.1186 /$ scrt506

25 Allegra A, Innao V, Russo S, Gerace D, Alonci A and Musolino $\mathrm{C}$ : Anticancer activity of curcumin and its analogues: Preclinical and clinical studies. Cancer Invest (1): 1-22, 2017. PMID: 27996308. DOI: 10.1080/07357907.2016.1247166

26 Singletary K, MacDonald C, Wallig M and Fisher C: Inhibition of 7,12-dimethylbenz[a]anthracene (DMBA)-induced mammary tumorigenesis and DMBA-DNA adduct formation by curcumin. Cancer Lett 103(2): 137-141, 1996. PMID: 8635149. DOI: 10.1016/0304-3835(96)04224-3

27 Banik U, Parasuraman S, Adhikary AK and Othman NH: Curcumin: the spicy modulator of breast carcinogenesis. J Exp Clin Cancer Res 36(1): 98, 2017. PMID: 28724427. DOI: 10.1186/s13046-017-0566-5

28 Khajuria A, Zutshi U and Bedi KL: Permeability characteristics of piperine on oral absorption--an active alkaloid from peppers and a bioavailability enhancer. Indian J Exp Biol 36(1): 46-50, 1998. PMID: 9536651.
29 Shoba G, Joy D, Joseph T, Majeed M, Rajendran R and Srinivas P: Influence of piperine on the pharmacokinetics of curcumin in animals and human volunteers. Planta Med 64(04): 353-356, 1998. PMID: 9619120. DOI: 10.1055/s-2006-957450

30 Zheng J, Zhou Y, Li Y, Xu DP, Li S and Li HB: Spices for prevention and treatment of cancers. Nutrients 8(8): 495, 2016. PMID: 27529277. DOI: 10.3390/nu8080495

31 Do MT, Kim HG, Choi JH, Khanal T, Park BH, Tran TP, Jeong TC and Jeong HG: Antitumor efficacy of piperine in the treatment of human HER2-overexpressing breast cancer cells. Food Chem 141(3): 2591-2599, 2013. PMID: 23870999. DOI: 10.1016/j.foodchem.2013.04.125

32 Lai LH, Fu QH, Liu Y, Jiang K, Guo QM, Chen QY, Yan B, Wang QQ and Shen JG: Piperine suppresses tumor growth and metastasis in vitro and in vivo in a $4 \mathrm{~T} 1$ murine breast cancer model. Acta Pharmacol Sin 33(4): 523-530, 2012. PMID: 22388073. DOI: 10.1038/aps.2011.209

33 Li S, Lei Y, Jia Y, Li N, Wink M and Ma Y: Piperine, a piperidine alkaloid from Piper nigrum re-sensitizes P-gp, MRP1 and BCRP dependent multidrug resistant cancer cells. Phytomedicine 19(1): 83-87, 2011. PMID: 21802927. DOI: 10.1016/j.phymed.2011.06.031

34 Motiwala MN and Rangari VD: Combined effect of paclitaxel and piperine on a MCF-7 breast cancer cell line in vitro: Evidence of a synergistic interaction. Synergy 2(1): 1-6, 2015. DOI: 10.1016/j.synres.2015.04.001

35 Khamis AAA, Ali EMM, El-Moneim MAA, Abd-Alhaseeb MM, El-Magd MA and Salim EI: Hesperidin, piperine and bee venom synergistically potentiate the anticancer effect of tamoxifen against breast cancer cells. Biomed Pharmacother 105: 1335-1343, 2018. PMID: 30021371. DOI: 10.1016/ j.biopha.2018.06.105

36 Abdelhamed S, Yokoyama S, Refaat A, Ogura K, Yagita H, Awale S and Saiki I: Piperine enhances the efficacy of TRAILbased therapy for triple-negative breast cancer cells. Anticancer Res 34(4): 1893-1899, 2014. PMID: 24692724.

37 Greenshields AL, Doucette CD, Sutton KM, Madera L, Annan H, Yaffe PB, Knickle AF, Dong Z and Hoskin DW: Piperine inhibits the growth and motility of triple-negative breast cancer cells. Cancer Lett 357(1): 129-140, 2015. PMID: 25444919. DOI: $10.1016 /$ j.canlet.2014.11.017

38 Thammineni N, Lakshmi MV, Nag KN, Abbas ZS, Thammineni P, Kanaka B and Harikrishna VS: Studying whether curcumin and piperine sensitize breast cancer cells and breast cancerinitiating cells to radiation. Int J Radiat Oncol 90(1): S246, 2014. DOI: 10.1016/j.ijrobp.2014.05.868

39 Atwell LL, Beaver LM, Shannon J, Williams DE, Dashwood $\mathrm{RH}$ and Ho E: Epigenetic regulation by sulforaphane: opportunities for breast and prostate cancer chemoprevention. Curr Pharmacol Reports 1(2): 102-111, 2015. PMID: 26042194. DOI: $10.1007 / \mathrm{s} 40495-014-0002-\mathrm{x}$

40 Pledgie-Tracy A, Sobolewski MD and Davidson NE: Sulforaphane induces cell type-specific apoptosis in human breast cancer cell lines. Mol Cancer Ther 6(3): 1013-1021, 2007. PMID: 17339367. DOI: 10.1158/1535-7163.MCT-060494

41 Meeran SM, Patel SN and Tollefsbol TO: Sulforaphane causes epigenetic repression of hTERT expression in human breast cancer cell lines. PLoS One 5(7): e11457, 2010. PMID: 20625516. DOI: 10.1371/journal.pone.0011457 
42 Ramirez MC and Singletary K: Regulation of estrogen receptor $\alpha$ expression in human breast cancer cells by sulforaphane. J Nutr Biochem 20(3): 195-201, 2009. PMID: 18602823. DOI: $10.1016 /$ j.jnutbio.2008.02.002.

43 Jackson SJT and Singletary KW: Sulforaphane inhibits human MCF-7 mammary cancer cell mitotic progression and tubulin polymerization. J Nutr 134(9): 2229-2236, 2004. PMID: 15333709. DOI: $10.1093 / \mathrm{jn} / 134.9 .2229$

44 Azarenko O, Okouneva T, Singletary KW, Jordan MA and Wilson L: Suppression of microtubule dynamic instability and turnover in MCF7 breast cancer cells by sulforaphane. Carcinogenesis 29(12): 2360, 2008. PMID: 18952594. DOI: 10.1093/carcin/bgn241

45 Katz E, Nisani S and Chamovitz DA: Indole-3-carbinol: a plant hormone combatting cancer. F1000Research 7: 689, 2018 PMID: 29904587. DOI: 10.12688/f1000research.14127.1

46 Bosetti C, Negri E, Kolonel L, Ron E, Franceschi S, PrestonMartin S, McTiernan A, Dal Maso L, Mark SD, Mabuchi K and Land C: A pooled analysis of case-control studies of thyroid cancer. VII. Cruciferous and other vegetables (International). Cancer Causes Control 13(8): 765-775, 2002. PMID: 124209 56. DOI: $10.1023 / \mathrm{A}: 1020243527152$

47 Rahman KW, Aranha OP and Sarkar FH: Indole-3-carbinol (I3C) induces apoptosis in tumorigenic but not in nontumorigenic breast epithelial cells. Nutr Cancer 45(1): 101-112, 2003. PMID: 12791510. DOI: $10.1207 / \mathrm{S} 15327914 \mathrm{NC} 4501 \_12$

48 Aggarwal BB and Ichikawa H: Molecular targets and anticancer potential of indole-3-carbinol and its derivatives. Cell Cycle 4(9): 1201-1215, 2005. PMID: 16082211. DOI: 10.4161/ cc.4.9.1993

49 Liu X and Lv K: Cruciferous vegetables intake is inversely associated with risk of breast cancer: A meta-analysis. Breast 22(3): 309-313, 2013. PMID: 22877795. DOI: 10.1016/j.breast. 2012.07.013

50 Zhang NQ, Ho SC, Mo XF, Lin FY, Huang WQ, Luo H, Huang $\mathrm{J}$ and Zhang CX: Glucosinolate and isothiocyanate intakes are inversely associated with breast cancer risk: A case-control study in China. Br J Nutr 119(8): 957-964, 2018. PMID: 29644960. DOI: $10.1017 / \mathrm{S} 0007114518000600$

51 Lin T, Zirpoli GR, McCann SE, Moysich KB, Ambrosone CB and Tang L: Trends in cruciferous vegetable consumption and associations with breast cancer risk: A case-control study. Curr Dev Nutr 1(8): e000448, 2017. PMID: 29955715. DOI: $10.3945 / \mathrm{cdn} .117 .000448$

52 Bosetti C, Filomeno M, Riso P, Polesel J, Levi F, Talamini R, Montella M, Negri E, Franceschi $S$ and La Vecchia C: Cruciferous vegetables and cancer risk in a network of casecontrol studies. Ann Oncol 23(8): 2198-2203, 2012. PMID: 22328735. DOI: $10.1093 /$ annonc/mdr604

53 Gaudet MM, Britton JA, Kabat GC, Steck-Scott S, Eng SM, Teitelbaum SL, Terry MB, Neugut AI and Gammon MD: Fruits, vegetables, and micronutrients in relation to breast cancer modified by menopause and hormone receptor status. Cancer Epidemiol Prev Biomarkers 13(9): 1485-1494, 2004. PMID: 15342450

54 Ambrosone CB, McCann SE, Freudenheim JL, Marshall JR, Zhang Y and Shields PG: Breast cancer risk in premenopausal women is inversely associated with consumption of broccoli, a source of isothiocyanates, but is not modified by GST genotype. J Nutr 134(5): 1134-1138, 2004. PMID: 15113959. DOI: $10.1093 / \mathrm{jn} / 134.5 .1134$
55 Chahar MK, Sharma N, Dobhal MP and Joshi YC: Flavonoids: A versatile source of anticancer drugs. Pharmacogn Rev (9): 1, 2011. PMID: 22096313. DOI: 10.4103/0973-7847.79093

56 Gibellini L, Pinti M, Nasi M, Montagna JP, De Biasi S, Roat E, Bertoncelli L, Cooper EL and Cossarizza A: Quercetin and cancer chemoprevention. Evid Based Complement Alternat Med 2011: 591356, 2011. PMID: 21792362. DOI: 10.1093/ ecam/neq053

57 Rauf A, Imran M, Khan IA, ur-Rehman M, Gilani SA, Mehmood Z and Mubarak MS: Anticancer potential of quercetin: A comprehensive review. Phyther Res 32(11): 21092130, 2018. PMID: 30039547. DOI: 10.1002/ptr.6155

58 Carlos-Reyes A, López-González JS, Meneses-Flores M, Gallardo-Rincón D, Ruíz-García E, Marchat LA, Astudillo de la Vega H, Hernández de la Cruz ON and López-Camarillo C: Dietary compounds as epigenetic modulating agents in cancer. Front Genet 10: 79, 2019. PMID: 30881375. DOI: 10.3389/ fgene.2019.00079

59 Iriti M, Kubina R, Cochis A, Sorrentino R, Varoni EM, KabałaDzik A, Azzimonti B, Dziedzic A, Rimondini L and Wojtyczka RD: Rutin, a quercetin glycoside, restores chemosensitivity in human breast cancer cells. Phyther Res 31(10): 1529-1538, 2017. PMID: 28752532. DOI: $10.1002 /$ ptr.5878

60 Li S, Yuan S, Zhao Q, Wang B, Wang X and Li K: Quercetin enhances chemotherapeutic effect of doxorubicin against human breast cancer cells while reducing toxic side effects of it. Biomed Pharmacother 100: 441-447, 2018. PMID: 29475141. DOI: 10.1016/j.biopha.2018.02.055

61 Staedler D, Idrizi E, Kenzaoui BH and Juillerat-Jeanneret L: Drug combinations with quercetin: doxorubicin plus quercetin in human breast cancer cells. Cancer Chemother Pharmacol 68(5): 1161-1172, 2011. PMID: 21400027. DOI: 10.1007/s00 280-011-1596-x

62 Oh SJ, Kim O, Lee JS, Kim JA, Kim MR, Choi HS, Shim JH, Kang KW and Kim YC: Inhibition of angiogenesis by quercetin in tamoxifen-resistant breast cancer cells. Food Chem Toxicol 48(11): 3227-3234, 2010. PMID: 20804812. DOI: 10.1016/ j.fct.2010.08.028

63 Hui C, Qi X, Qianyong Z, Xiaoli P, Jundong Z and Mantian M: Flavonoids, flavonoid subclasses and breast cancer risk: A metaanalysis of epidemiologic studies. PLoS One 8(1): e54318, 2013. PMID: 23349849. DOI: 10.1371/journal.pone. 0054318

64 Rossi M, Bosetti C, Negri E, Lagiou P and Vecchia C La: Flavonoids, proanthocyanidins, and cancer risk: A network of case-control studies from Italy. Nutr Cancer 62(7): 871-877, 2010. PMID: 20924962. DOI: 10.1080/01635581.2010.509534

65 Bosetti C, Spertini L, Parpinel M, Gnagnarella P, Lagiou P, Negri E, Franceschi S, Montella M, Peterson J, Dwyer J and Giacosa A: Flavonoids and breast cancer risk in Italy. Cancer Epidemiol Biomarkers Prev 14(4): 805-808, 2005. PMID: 15824147. DOI: 10.1158/1055-9965.EPI-04-0838

66 Peterson J, Lagiou P, Samoli E, Lagiou A, Katsouyanni K, La Vecchia C, Dwyer J and Trichopoulos D: Flavonoid intake and breast cancer risk: a case-control study in Greece. Br J Cancer 89(7): 1255-1259, 2003. PMID: 14520456. DOI: 10.1038/sj.bjc. 6601271

67 Knekt P, Kumpulainen J, Järvinen R, Rissanen H, Heliövaara M, Reunanen A, Hakulinen T and Aromaa A: Flavonoid intake and risk of chronic diseases. Am J Clin Nutr 76(3): 560-568, 2002. PMID: 12198000. DOI: 10.1093/ajen/76.3.560 
68 Dufresne CJ and Farnworth ER: A review of latest research findings on the health promotion properties of tea. J Nutr Biochem 12(7): 404-421, 2001. PMID: 11448616. DOI: 10.1016/S0955-2863(01)00155-3

69 Weisburger JH and Chung FL: Mechanisms of chronic disease causation by nutritional factors and tobacco products and their prevention by tea polyphenols. Food Chem Toxicol 40(8): 1145-1154, 2002. PMID: 12067577. DOI: 10.1016/S0278-6915 (02)00044-3

70 Yiannakopoulou EC: Interaction of green tea catechins with breast cancer endocrine treatment: A systematic review. Pharmacology 94(5-6): 245-248, 2014. PMID: 25471334. DOI: $10.1159 / 000369170$

71 Sur S and Panda CK: Molecular aspects of cancer chemopreventive and therapeutic efficacies of tea and tea polyphenols. Nutrition 43-44: 8-15, 2017. PMID: 28935149. DOI: 10.1016/j.nut.2017.06.006

72 Rafieian-Kopaei $M$ and Movahedi M: Breast cancer chemopreventive and chemotherapeutic effects of Camellia Sinensis (green tea): an updated review. Electronic physician 9(2): 3838-3844, 2017. PMID: 28465816. DOI: 10.19082/3838.

73 Beltz LA, Bayer DK, Moss AL and Simet IM: Mechanisms of cancer prevention by green and black tea polyphenols. Anticancer Agents Med Chem 6(5): 389-406, 2006. PMID: 17017850. DOI: $10.2174 / 187152006778226468$

$74 \mathrm{Xu} \mathrm{Y,} \mathrm{Ho} \mathrm{CT,} \mathrm{Amin} \mathrm{SG,} \mathrm{Han} \mathrm{C} \mathrm{and} \mathrm{Chung} \mathrm{FL:} \mathrm{Inhibition} \mathrm{of}$ tobacco-specific nitrosamine-induced lung tumorigenesis in $\mathrm{A} / \mathrm{J}$ mice by green tea and its major polyphenol as antioxidants. Cancer Res 52(14): 3875-3879, 1992. PMID: 1617663. DOI: 10.1016/0169-5002(93)90327-T

75 Narisawa T and Fukaura Y: A very low dose of green tea polyphenols in drinking water prevents $\mathrm{N}$-methyl-N-nitrosoureainduced colon carcinogenesis in F344 rats. Japanese J Cancer Res 84(10): 1007-1009, 1993. PMID: 8226273. DOI: 10.1111/j.13497006.1993.tb02792.x

76 Kaur S, Greaves P, Cooke DN, Edwards R, Steward WP, Gescher AJ and Marczylo TH: Breast cancer prevention by green tea catechins and black tea theaflavins in the C3 (1) SV40 $\mathrm{T}, \mathrm{t}$ antigen transgenic mouse model is accompanied by increased apoptosis and a decrease in oxidative DNA adducts. J Agric Food Chem 55(9): 3378-3385, 2007. PMID: 17407311. DOI: $10.1021 /$ jf0633342

77 Lin D-X, Thompson PA, Teitel C, Chen J-S and Kadlubar FF: Direct reduction of $\mathrm{N}$-acetoxy-PhIP by tea polyphenols: a possible mechanism for chemoprevention against PhIP-DNA adduct formation. Mutat Res Mol Mech Mutagen 523-524: 193200, 2003. PMID: 12628517. DOI: 10.1016/S0027-5107(02)0 0335-4

78 Gianfredi V, Vannini S, Moretti M, Villarini M, Bragazzi NL, Izzotti A and Nucci D: Sulforaphane and epigallocatechin gallate restore estrogen receptor Expression by modulating epigenetic events in the breast cancer cell line MDA-MB-231: a systematic review and meta-analysis. $J$ Nutrigenet Nutrigenomics 10(3-4): 126-135, 2017. PMID: 29040973. DOI: $10.1159 / 000480636$

79 Chikara S, Nagaprashantha LD, Singhal J, Horne D, Awasthi S and Singhal SS: Oxidative stress and dietary phytochemicals: Role in cancer chemoprevention and treatment. Cancer Lett 413: 122-134, 2018. PMID: 29113871. DOI: 10.1016/j.canlet. 2017.11.002
80 Thangapazham RL, Singh AK, Sharma A, Warren J, Gaddipati JP and Maheshwari RK: Green tea polyphenols and its constituent epigallocatechin gallate inhibits proliferation of human breast cancer cells in vitro and in vivo. Cancer Lett 245(1-2): 232-241, 2007. PMID: 16519995. DOI: 10.1016/j.canlet.2006.01.027

81 Min NY, Kim JH, Choi JH, Liang W, Ko YJ, Rhee S, Bang H, Ham SW, Park AJ and Lee KH: Selective death of cancer cells by preferential induction of reactive oxygen species in response to (-)-epigallocatechin-3-gallate. Biochem Biophys Res Commun 421(1): 91-97, 2012. PMID: 22487794. DOI: 10.1016/j.bbrc.2012.03.120

82 Ogunleye AA, Xue F and Michels KB: Green tea consumption and breast cancer risk or recurrence: a meta-analysis. Breast Cancer Res Treat 119(2): 477-484, 2010. PMID: 19437116. DOI: $10.1007 / \mathrm{s} 10549-009-0415-0$

83 Gianfredi V, Nucci D, Abalsamo A, Acito M, Villarini M, Moretti $\mathrm{M}$ and Realdon S: Green tea consumption and risk of breast cancer and recurrence-A systematic review and metaanalysis of observational studies. Nutrients 10(12): 1886, 2018. PMID: 30513889. DOI: 10.3390/nu10121886

84 Young TK, Kelly JJ, Friborg J, Soininen L and Wong KO: Cancer among circumpolar populations: an emerging public health concern. Int J Circumpolar Health 75(1): 29787, 2016. PMID: 26765259. DOI: 10.3402/ijch.v75.29787

85 Hori M, Matsuda T, Shibata A, Katanoda K, Sobue T and Nishimoto H: Cancer incidence and incidence rates in Japan in 2009: a study of 32 population-based cancer registries for the Monitoring of Cancer Incidence in Japan (MCIJ) project. Jpn J Clin Oncol 45(9): 884-891, 2015. PMID: 26142437. DOI: 10.1093/jjco/hyv088

86 Bhoo-Pathy N, Yip CH, Hartman M, Uiterwaal CS, Devi BC, Peeters PH, Taib NA, van Gils CH and Verkooijen HM: Breast cancer research in Asia: adopt or adapt Western knowledge? Eur J Cancer 49(3): 703-709, 2013. PMID: 23040889. DOI: 10.1016/j.ejca.2012.09.014

87 Lands WE, Hamazaki T, Yamazaki K, Okuyama H, Sakai K, Goto Y and Hubbard VS: Changing dietary patterns. Am J Clin Nutr 51(6): 991-993, 1990. PMID: 2190465. DOI: 10.1093/ ajen/51.6.991

88 Karmali RA, Marsh J and Fuchs C: Effect of omega-3 fatty acids on growth of a rat mammary tumor. JNCI J Natl Cancer Inst 73(2): 457-461, 1984. PMID: 6087007. DOI: 10.1093/jnci/ 73.2 .457

89 Rose DP, Connolly JM and Meschter CL: Effect of dietary fat on human breast cancer growth and lung metastasis in nude mice. JNCI J Natl Cancer Inst 83(20): 1491-1495, 1991. PMID: 1920496. DOI: 10.1093/jnci/83.20.1491.

90 Chajès V, Sattler W, Stranzl A and Kostner GM: Influence of n-3 fatty acids on the growth of human breast cancer cells in vitro: relationship to peroxides and vitamin-E. Breast Cancer Res Treat 34(3): 199-212, 1995. PMID: 7579484.

91 Serini $S$ and Calviello G: Modulation of Ras/ERK and phosphoinositide signaling by long-chain n-3 PUFA in breast cancer and their potential complementary role in combination with targeted drugs. Nutrients 9(3): 185, 2017. PMID: 28241486. DOI: $10.3390 /$ nu9030185

92 Fabian CJ, Kimler BF and Hursting SD: Omega-3 fatty acids for breast cancer prevention and survivorship. Breast Cancer Res 17(1): 62, 2015. PMID: 25936773. DOI: 10.1186/s13058015-0571-6 
93 Zheng J-S, Hu X-J, Zhao Y-M, Yang J and Li D: Intake of fish and marine n-3 polyunsaturated fatty acids and risk of breast cancer: meta-analysis of data from 21 independent prospective cohort studies. BMJ 346: f3706-f3706, 2013. PMID: 23814120. DOI: $10.1136 / \mathrm{bmj} . \mathrm{f} 3706$

94 Yang B, Ren X-L, Fu Y-Q, Gao J-L and Li D: Ratio of n-3/n-6 PUFAs and risk of breast cancer: a meta-analysis of 274135 adult females from 11 independent prospective studies. BMC Cancer 14(1): 105, 2014. PMID: 24548731. DOI: 10.1186/ 1471-2407-14-105

95 Chilton F, Dutta R, Reynolds L, Sergeant S, Mathias R and Seeds M: Precision nutrition and omega-3 polyunsaturated fatty acids: A case for personalized supplementation approaches for the prevention and management of human diseases. Nutrients 9(11): 1165, 2017. PMID: 29068398. DOI: 10.3390/nu9111165

96 Astorg P, Arnault N, Czernichow S, Noisette N, Galan P and Hercberg S: Dietary intakes and food sources of $n-6$ and $n-3$ PUFA in french adult men and women. Lipids 39(6): 527-535, 2004. PMID: 15554151. DOI: 10.1007/s11745-004-1259-6

97 Kris-Etherton PM, Taylor DS, Yu-Poth S, Huth P, Moriarty K, Fishell V, Hargrove RL, Zhao $G$ and Etherton TD: Polyunsaturated fatty acids in the food chain in the United States. Am J Clin Nutr 71(1): 179S-188S, 2000. PMID: 10617969. DOI:10.1093/ajcn/71.1.179S

98 Ollis TE, Meyer BJ and Howe PRC: Australian food sources and intakes of omega- 6 and omega-3 polyunsaturated fatty acids. Ann Nutr Metab 43(6): 346-355, 1999. PMID: 10725768. DOI: $10.1159 / 000012803$

99 Burdge GC and Calder PC: Dietary $\alpha$-linolenic acid and healthrelated outcomes: a metabolic perspective. Nutr Res Rev 19(1): 26-52, 2006. PMID: 19079874. DOI: 10.1079/NRR2005113.

100 Calder PC: Mechanisms of action of (n-3) fatty acids. J Nutr 142(3): 592S-599S, 2012. PMID: 22279140. DOI: 10.3945/ jn.111.155259

101 Domenichiello AF, Kitson AP and Bazinet RP: Is docosahexaenoic acid synthesis from $\alpha$-linolenic acid sufficient to supply the adult brain? Prog Lipid Res 59: 54-66, 2015. PMID: 25920364. DOI: 10.1016/j.plipres.2015.04.002
102 Pawlosky RJ, Hibbeln JR, Novotny JA and Salem N: Physiological compartmental analysis of alpha-linolenic acid metabolism in adult humans. J Lipid Res 42(8): 1257-1265, 2001. PMID: 11483627.

103 Emken EA, Adlof RO and Gulley RM: Dietary linoleic acid influences desaturation and acylation of deuterium-labeled linoleic and linolenic acids in young adult males. Biochim Biophys Acta - Lipids Lipid Metab 1213(3): 277-288, 1994. PMID: 7914092. DOI: 10.1016/0005-2760(94)00054-9

104 Blasbalg TL, Hibbeln JR, Ramsden CE, Majchrzak SF and Rawlings RR: Changes in consumption of omega- 3 and omega6 fatty acids in the United States during the 20th century. Am J Clin Nutr 93(5): 950-962, 2011. PMID: 21367944. DOI: 10.3945/ajcn.110.006643

105 Astorg P, Arnault N, Czernichow S, Noisette N, Galan P and Hercberg S: Dietary intakes and food sources of n-6 and n-3 PUFA in French adult men and women. Lipids 39(6): 527-535, 2004. PMID: 15554151. DOI: 10.1007/s11745-004-1259-6

106 Harris WS, Mozaffarian D, Lefevre M, Toner CD, Colombo J, Cunnane SC, Holden JM, Klurfeld DM, Morris MC and Whelan J: Towards establishing dietary reference intakes for eicosapentaenoic and docosahexaenoic acids. J Nutr 139(4): 804S-819S, 2009. PMID: 19244379. DOI: 10.3945/jn.108. 101329

107 Gomes MA, Jia X, Kolenski I, Duncan AM and Meckling KA: The role of background diet on the effects of eicosapentaenoic acid and docosahexaenoic acid supplementation in healthy premenopausal women: a randomized, cross-over, controlled study. Lipids Health Dis 15(1): 168, 2016. PMID: 27687127. DOI: 10.1186/s12944-016-0341-1

Received April 23, 2019

Revised June 5, 2019

Accepted June 21, 2019 